\title{
Aeration Irrigation Can Improve Growth of Table Grape cv. Red Globe (Vitis vinifera L.) in Greenhouse
}

\author{
Fengyun Zhao', Junli Sun ${ }^{1}$, Songlin Yu, Huaifeng Liu' ${ }^{2}$, and Kun $\mathbf{Y u}^{2}$
} Department of Horticulture, College of Agriculture/The Key Laboratory of Characteristics of Fruit and Vegetable Cultivation and Utilization of Germplasm Resources of the Xinjiang Production and Construction Corps, Shihezi University, Shihezi 832003, P.R. China

Additional index words. aeration, subsurface drip irrigation, grape, soil microbial community

\begin{abstract}
Aeration through subsurface drip irrigation (SDI) can promote plant growth and increase crop yield; however, more research is focused on annual crops, and there are few studies on perennial crops. We have studied a new type of SDI (SDI with tanks) suitable for cultivation and production of perennial fruit trees and photovoltaic aeration device in greenhouse. The results showed that aeration irrigation promoted the growth of new leaves, fine roots, and new branches of grape, regulated $\mathrm{O}_{2} / \mathrm{CO}_{2}$ content in rhizosphere soil, and accelerated air exchange in rhizosphere soil. This study showed that aeration irrigation did not change the structure of bacteria and fungi but significantly increased the abundance of aerobic bacteria, such as Nitrospira and Cytophagia. Moreover, it promoted the increase of Pseudomonas and Aspergillus related to phosphate solubilization, that of Bacillus related to potassium solubilization, and that of Fusarium related to organic matter (OM) decomposition. This study shows that aeration irrigation through SDI with tanks can promote grape growth, which may be related to the ability of aeration irrigation to change the gas composition of rhizosphere soil, optimize the structure of rhizosphere soil microorganism.
\end{abstract}

Soil compaction is one of the major problems faced in modern agriculture (Rücknagel et al., 2015). With heavy rainfall, the associated water saturation of the soil caused by drip irrigation and mechanical rolling will result in soil compaction. Once air capacity decreases and gas exchange is restricted, the physical and chemical properties of soil worsen, which affects the normal growth of the crops, resulting in reduced production (Nawaz et al., 2013). Aeration irrigation is an improvement of SDI, which has been studied for nearly 20 years (Greenway et al., 2006). Aeration irrigation involves the delivery of oxygen or oxygenated material to the root zone of the crop through SDI systems to improve soil aeration and to meet the needs of root growth and development, thereby improving crop yield and quality (Bhattarai et al., 2004; Lei et al., 2015). Recent report on oxygenation irrigation experiments confirmed that using of oxygenated SDI water

\footnotetext{
Received for publication 16 Nov. 2018. Accepted for publication 23 Jan. 2019.

This research was supported by the Natural Science Foundation of China (31760550), Corps major scientific and technological project plan (2016AA002), and Basic Project of Shihezi University (20170845; Gxjs2015-zdgg04). We acknowledge Beijing Novogene Bioinformatics Technology Co., Ltd. for deep 16S rRNA and ITS barcode sequencing. We thank Elsevier Webshop for assistance with language.

${ }^{1} \mathrm{Co}$-first authors.

${ }^{2}$ Corresponding authors. E-mail: yukun409@163. com orlhfeng7227@sohu.com.
}

could increase crop yields, water use efficiency and salinity tolerance, the effect was more significant on heavy clay soils (Abuarab et al., 2013; Bhattarai et al., 2006, 2008; Ityel et al., 2014). Li et al. (2016b) showed that soil aeration enhanced greenhouse tomato plant growth, yield fruit shape, and nutritional quality. Research on capsicum showed that increased oxygen concentration in the root zone by $5 \%$ by allowing roots to penetrate into the capillary barrier gravel layer and improved biomass and fruit yield by $16 \%$ and $18 \%$, respectively (Ityel et al., 2014). This research showed that aeration irrigation was an efficient technology with a certain application prospect. However, in production, it was found that because of the limited infiltration range of traditional SDI, it was advantageous for annual crops such as tomato, maize, soybean, and chickpea, but there have been relatively few reports on perennial and large root fruit trees.

Ben-Noah and Friedman (2016) found that addition of a perforated sphere around the irrigation aeration dripper promotes significant increases in soil oxygen concentrations compared with direct air injection. This suggests that the efficiency of existing drip irrigation methods could be improved by increasing the efficiency of aeration irrigation. SDI with tanks is a technique newly developed by our research team that can effectively solve the problem of small infiltration range. This new method is suitable for applications in the forestry and fruit industries. Compared with traditional surface drip irrigation, SDI with tanks has the advan- tages of water savings of more than $30 \%$, promotion of deeper root system growth, improvement of fertilizer utilization, and reduced labor requirement (Yu et al., 2014, 2015). Moreover, this method can be used for aeration without extensive increases in cost.

Rhizosphere soil microorganisms are the most important and active parts of soil ecosystems (Abbott and Murphy, 2003; Zhu et al., 2014) and reflect varieties in soil quality in a sensitive, timely, and accurate manner. High microbial diversity in the rhizosphere has previously been shown to enhance plant productivity (Fierer et al., 2013; Lau and Lennon, 2011). Soil tillage often affects the soil microbial community by changing the soil structure; therefore, studies of soil microorganisms can provide insight into the effects of tillage on soil ecosystems (Carpenter-Boggs et al., 2003; Ji et al., 2013). Most studies have focused on the effects of aeration on plant growth, yield, and water use efficiency (Abuarab et al., 2013; Niu et al., 2013), but few reports have described the effects of aeration on soil microbial diversity, particularly that using SDI or SDI with tanks.

At present, the grapes cultivated in greenhouses in China are more than $1.33 \times 10^{3} \mathrm{~km}^{2}$ (Zhao et al., 2018). The intensive production, excessive irrigation, agricultural machinery, excessive fertilization, and reduced tillage in greenhouse grape cultivation and other factors all lead to soil compaction, resulting in hypoxia stress in the root zone and limiting the increase of the output and quality (Smith et al., 2013). Therefore, aeration irrigation has a certain potential application in greenhouse grape cultivation. However, there have been no report on the effects of aeration irrigation through SDI on the growth and development of grapes. In this study, 3-yearold 'Red Globe' grape plants were used as test materials in a box planting experiment in greenhouses; the carbon isotope tracer method, 16S rRNA, and ITS gene amplicon sequencing were used as key technologies. The following questions were explored in this study: 1) Can aeration irrigation through SDI with tanks improve the content of oxygen in the soil of grape plants? 2) Does aeration irrigation affect the content of soil microorganisms in the rhizosphere? Is the growth of grape plants in greenhouses related to the rhizosphere microorganisms and gas composition of rhizosphere soil? What is the relationship between microbial diversity in rhizosphere soil and the growth of grape plants? This research can provide a theoretical basis for the application and popularization of aeration irrigation through SDI with tanks in greenhouse grape cultivation.

\section{Materials and Methods}

Experimental design. The experiment was conducted from Apr. to Sept. 2016 in a greenhouse (108 $\mathrm{m}$ long and $7 \mathrm{~m}$ wide) at Shihezi University, located in Shihezi city, Xinjiang Uygur autonomous region, Northwest China (lat. $45^{\circ} 19^{\prime} \mathrm{N}$, long. $86^{\circ} 03^{\prime} \mathrm{E}$ ). The temperature range is 17 to $33^{\circ} \mathrm{C}$, and the 
relative humidity is $60 \%$ to $80 \%$ in the greenhouse during the experiment.

In two treatments, aeration and no aeration (CK), with 15 repetitions, a single 'Red Globe' grape cutting seedling was transplanted in each box (Fig. 1). The box length and width were each $40 \mathrm{~cm}$, and the height was $60 \mathrm{~cm}$. The soil was collected from 0 to $20 \mathrm{~cm}$ depth of a vineyard with 10 years of planting of 'Red Globe' grape in the experimental station and passed through a 40-mesh sieve. When loading, each $10 \mathrm{~cm}$ was considered one layer and compacted. After completion of loading, further compaction was performed by irrigation (Zhao et al., 2017). The basis physicochemical properties of the box soil were as follows: bulk density, 1.40 $\mathrm{g} \cdot \mathrm{cm}^{-3}$; field water holding capacity, $24.6 \%$ (percentage of dry soil mass); $\mathrm{pH}, 6.56$; OM, $13.61 \mathrm{~g} \cdot \mathrm{kg}^{-1} ; \mathrm{NH}_{4}^{+}-\mathrm{N}, 58.4 \mathrm{mg} \cdot \mathrm{kg}^{-1} ; \mathrm{NO}_{3}{ }^{-}-\mathrm{N}$, $44.7 \mathrm{mg} \cdot \mathrm{kg}^{-1}$; OP, $43.6 \mathrm{mg} \cdot \mathrm{kg}^{-1}$; and AK, 305 $\mathrm{mg} \cdot \mathrm{kg}^{-1}$. On 6 May 2016, 3-year-old 'Red Globe' grape cuttings from seedlings with the same growth were transplanted in the cultivation box using SDI with tanks for irrigation. The same amounts of irrigation and fertilizer was used for both $\mathrm{CK}$ and aeration treatment; aeration treatment was initiated 1 month after transplanting.

The experiment was conducted using a custom-designed "water-fertilizer-air" integration system (see Zhao et al., 2018). Electric energy was supplied by solar panels, and air compressors were used for gas injection processing; the pressure was $0.04 \mathrm{MPa}, 60$ $\mathrm{L} \cdot \mathrm{min}^{-1}$ (Zhao et al., 2018). The injection volume was selected according to the formula $\mathrm{V}=0.001 \mathrm{SH}\left(1-\rho_{\mathrm{b}} / \rho_{\mathrm{s}}\right)$ n (Li et al., 2016a), where $\mathrm{V}$ is the amount of each aerated liter (L); S is PVC box surface area in square centimeters; $\mathrm{H}$ is PVC box height of $60 \mathrm{~cm} ; \rho_{\mathrm{b}}$ refers to soil bulk density $(1.40$ $\left.\mathrm{g} \cdot \mathrm{cm}^{-3}\right) ; \rho_{\mathrm{s}}$ refers to the soil density, 2.65 $\mathrm{g} \cdot \mathrm{cm}^{-3}$; and $\mathrm{n}$ is the number of gas injection boxes, 15. According to this formula, the single minimum injection rate was $520.3 \mathrm{~L}$. Considering the dispersion effect and the pretest results of SDI with tanks, aeration treatment was set up to once daily for $20 \mathrm{~min}$ from 09:00 to 09:20 AM (Beijing time). Aeration treatment was based on SDI with tanks (Fig. 1); the aeration tank was a PVC tube with a diameter of $8.5 \mathrm{~cm}$ and height of $10 \mathrm{~cm}$. The upper part of the PVC pipe was sealed with an air inlet, and the lower part was not sealed. The aeration tank was buried at a depth of $25 \mathrm{~cm}, 5 \mathrm{~cm}$ from the plant.

\section{Measurement Indices and Methods}

Rhizosphere soil oxygen saturation. A portable oxygen analyzer was used to measure dissolved oxygen after irrigation, and the oxygen sensor was pushed into the soil at the depth of $0.25 \mathrm{~m}$ when measured. At $45 \mathrm{~d}$ after aeration treatment, three plants with uniform growth were selected for each treatment. The daily variation was measured on the third and seventh day after irrigation during the same irrigation period. The frequency of the measurement was once every $2 \mathrm{~h}$, and the sequence of measurement was the same as that of the first time.

Rhizosphere soil respiration. Determination of soil respiration intensity used an LI8100 open road soil carbon flux measurement system (LI-COR Inc., Lincoln, NE). Measurement time and frequency were in accordance

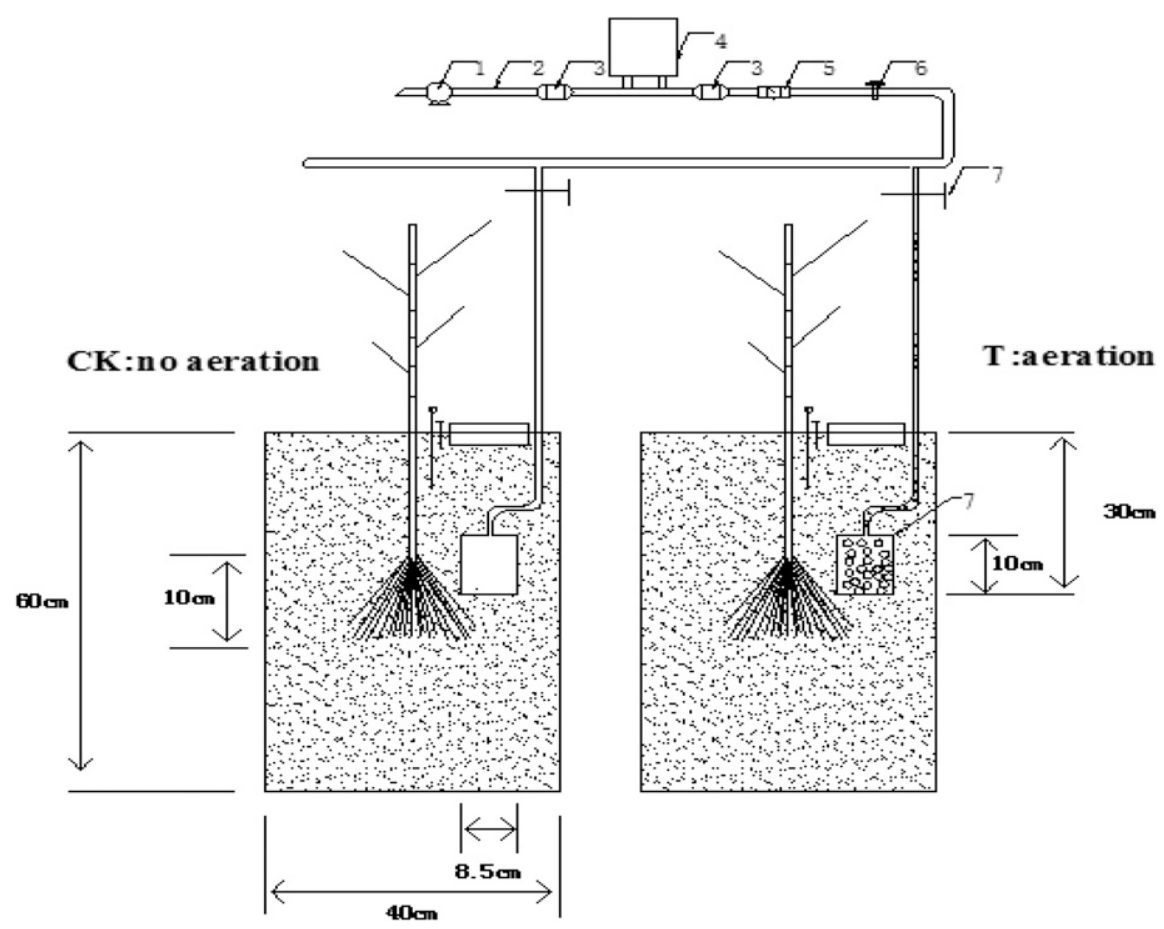

Fig. 1. Experimental design. (1) Water pump. (2) Main tube. (3) Filter. (4) Aeration system for subsurface drip irrigation (SDI) with tanks. (5) Water meter. (6) Switch. (7) Branch pipe of SDI with tanks. with oxygen measurements. A PVC tube (20 cm diameter and $11.5 \mathrm{~cm}$ height) was embedded in the soil, and the exposed soil surface was $2 \mathrm{~cm}$. Before measurement, all living bodies and debris on the soil surface of the PVC ring were removed, and the location of the PVC ring remained the same during the whole measurement.

Microbial community structure in rhizosphere soil. Soil sampling for this study was performed by the root drilling method after $90 \mathrm{~d}$ of aeration. After cutting the upper part of each plant, with the aeration tank as the center, soil samples were collected from four points measured evenly from the center of the aeration tank. The sampling positions were consistent for all boxes. Soil from each depth (total $100 \mathrm{~g}$ ) was collected at soil depths of 0 to 10,20 to 30 , and 40 to $50 \mathrm{~cm}$ for every box. Each treatment was assessed with nine samples; three samples were mixed as a composite sample. Soil samples for soil microorganisms are sampled and referenced to Shen et al. (2015).

Extraction of genomic DNA from samples was performed using the CTAB/SDS method. The purity and concentration of DNA were determined by agarose gel electrophoresis. The appropriate amount of samples in the centrifuge tube was diluted with sterile water to $1 \mathrm{ng} / \mu \mathrm{L}$. For polymerase chain reaction (PCR) amplification, diluted genomic DNA was used as a template, $515 \mathrm{~F}$ 806R as the primer for the 16S V4 region, and ITS1F-ITS2 as the primer for the ITS1 region. All PCR reactions were performed in $30-\mu \mathrm{L}$ reactions with $15 \mu \mathrm{L}$ of Phusion HighFidelity PCR Master Mix (New England Biolabs), forward and reverse primers $(0.2 \mu \mathrm{M}$ each), and $\approx 10 \mathrm{ng}$ of template DNA. Thermal cycling consisted of initial denaturation at $98{ }^{\circ} \mathrm{C}$ for $1 \mathrm{~min}$, followed by 30 cycles of denaturation at $98^{\circ} \mathrm{C}$ for $10 \mathrm{~s}$, annealing at $50{ }^{\circ} \mathrm{C}$ for $30 \mathrm{~s}$, and elongation at $72{ }^{\circ} \mathrm{C}$ for $30 \mathrm{~s}$, and then a finally extension $72{ }^{\circ} \mathrm{C}$ for $5 \mathrm{~min}$. PCR products were mixed in equidense ratios. The mixed PCR products were then purified using a Gene JET Gel Extraction Kit (Thermo Scientific) (Zhao et al., 2017). A sequencing library was constructed by using a NEB Next Ultra DNA Library Prep Kit for Illumina from New England Biolabs. The library was constructed by Qubit quantification and library testing. After validation, the library was sequenced on an Illumina MiSeq platform.

Plant biomass and ${ }^{13} \mathrm{C}$ value. The ${ }^{13} \mathrm{C}$ pulse-labeling experiment was conducted with three plants in each treatment on the 54 th day after aeration treatment. At the same time, three plants without ${ }^{13} \mathrm{C}$ pollution were selected as a blank control (plastic film isolation, used for the determination of the natural abundance of ${ }^{13} \mathrm{C}$ ). The labeled chamber was made of transparent agricultural film and an adjustable height scaffold. The length, width, and height of the labeled room were $0.5 \mathrm{~m} \times 0.5 \mathrm{~m} \times 1.5 \mathrm{~m}$. Before the marking, the fan, $\mathrm{CO}_{2}$ analyzer, four beakers with $0.5 \mathrm{~g}$ $\mathrm{Ba}^{13} \mathrm{CO}_{3}$ and a beaker with $\mathrm{Ba}^{12} \mathrm{CO}_{3}$ were put into the marking room and then sealed. ${ }^{12} \mathrm{CO}_{2}$ 
in the labeled chamber was absorbed by the sodium hydroxide absorption device before marking to improve the absorption and assimilation rate of ${ }^{13} \mathrm{CO}_{2}$. The labeling process started at 11:00 AM on a sunny day. $\mathrm{CO}_{2}$ analyzer monitoring marker was used to monitor $\mathrm{CO}_{2}$ concentration. Marking methods as described in An et al. (2015).

After $57 \mathrm{~d}$ of aeration treatment, three grape plants were selected for each destructive sampling. The whole plant was divided into old leaves (leaves that had grown before aeration), new leaves (leaves grown after aeration), old branches (branches of the previous year), new branches (branches of this year), fine roots (diameter $<2 \mathrm{~mm}$ ), and thick roots (diameter $>2 \mathrm{~mm}$ ). Sampling methods refer to Zhao et al. (2018). The samples were crushed in a mill and then sifted through a 150-mesh sieve; the samples were then bagged. $\delta^{13} \mathrm{C}$ value (\%) of bagged samples was measured in the DELTA V Advantage isotope ratio mass spectrometer. The $\delta^{13} \mathrm{C}$ value $(\%)$ was expressed relative to the Pee Dee Belemnite (PDB) standard: $\delta^{13} \mathrm{C}(\% \mathrm{oo})=$ $\left(\mathrm{R}_{\text {sample }} / \mathrm{R}_{\mathrm{PDB}}-1\right) \times 1000$, where $\mathrm{R}_{\text {sample }}$ is the ratio of ${ }^{13} \mathrm{C} /{ }^{12} \mathrm{C}$ in the sample and $\mathrm{R}_{\mathrm{PDB}}$ was equal to 0.0112372 (Werner and Brand, 2001).

After $90 \mathrm{~d}$ of aeration treatment, five grape plants were selected for each destructive sampling. The sampling method was the same as sample collection of ${ }^{13} \mathrm{C}$ determination. Plant biomass was determined after drying to constant weight.

Statistical analysis. The data were calculated by Excel 2013, and figures were made using AutoCAD 2007 and SigmaPlot 13.0 software. Data were compared via one-way analysis of variance using IBM SPSS 19.0 software (SPSS Inc., Chicago, IL), 0.05 was considered a significant difference and $0.01 \mathrm{a}$ highly significant difference.

\section{Results}

Rhizosphere soil respiration and oxygen saturation. As shown in Fig. 2, the oxygen saturation of soil in the aeration treatment increased first and then decreased on the third and seventh day after irrigation, reaching a
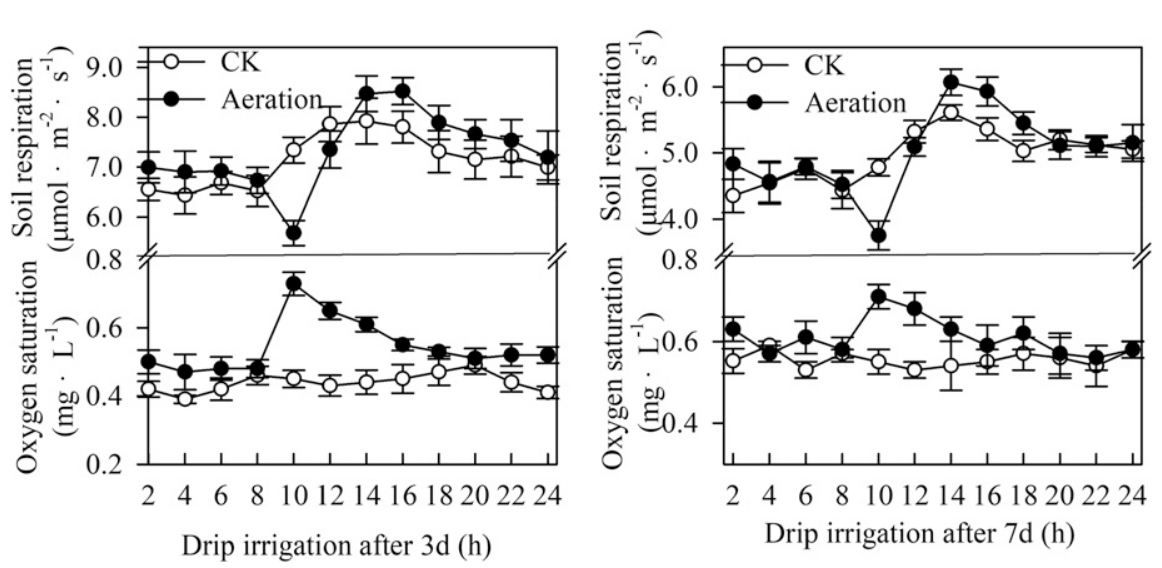

Fig. 2. Effect of aeration irrigation on grape rhizosphere soil respiration and oxygen saturation.

maximum at 10:00 AM. The oxygen saturation in the $\mathrm{CK}$ was relatively stable during the diurnal variation. Throughout the diurnal variation process, the oxygen saturation in the rhizosphere of the aeration treatment was higher than that of the $\mathrm{CK}$ treatment, and significantly higher at 10:00 $\mathrm{AM}, 12: 00 \mathrm{PM}$, and 2:00 PM $(P<0.05)$.

The variation trend of soil respiration intensity on the third and seventh days after irrigation was consistent. The variation trend of soil respiration intensity in the aeration treatment at first descended then decreased rapidly, becoming lowest at 10:00 AM; that in the CK treatment showed a trend of increasing and then decreasing during the diurnal variation (Fig. 2). The soil respiration intensity of the CK treatment was higher than that of aeration treatment at 10:00 $\mathrm{Am}$ and 12:00 PM. After that, the soil respiration intensity of aeration treatment increased rapidly, and it was significantly higher than that of CK treatment at 2:00 PM and 4:00 PM $(P<$ $0.05)$.

The oxygen saturation in the rhizosphere was $\approx 0.5 \mathrm{mg} \cdot \mathrm{L}^{-1}$ on the third day after irrigation, and it was $\approx 0.6 \mathrm{mg} \cdot \mathrm{L}^{-1}$ on the seventh day after irrigation. The soil respiration intensity was in the range of 5.0 to 8.0 $\mu \mathrm{mol} \cdot \mathrm{m}^{-2} \cdot \mathrm{s}^{-1}$ on the third day after irrigation, and it was in the range of 3.0 to 6.0 $\mu \mathrm{mol} \cdot \mathrm{m}^{-2} \cdot \mathrm{s}^{-1}$ on the seventh day after irrigation (Fig. 2).

Rhizosphere soil microbial community composition. The relative abundance of dominant phyla of the bacterial and fungal communities varied between the two treatments. Proteobacteria, Actinobacteria, Gemmatimonadetes, Acidobacteria, and Planctomycetes were the five most abundant phyla across all samples and accounted for $75.8 \%$ of the total bacterial sequences. Among the most abundant phyla, the aeration treatment had little effect on the community composition, except for Planctomycetacia with aeration treatment, which was significantly lower than that without aeration treatment (Fig. 3A). We further analyzed the differences in different bacterial classes and found that the relative abundance of Cytophagia and Nitrospira was higher at a soil depth of 20 to $30 \mathrm{~cm}$ in the aeration treatment compared with that in the CK treatment (Fig. 4). Specifically, the relative abundance of Cytophagia was significantly enhanced by $27.3 \%$, and the relative abundance of Nitrospira was significantly enhanced by $25.8 \%$.

For fungal phyla, Ascomycota and Basidiomycota were most abundant, accounting for $91.3 \%$ and $5.5 \%$, respectively. Interestingly, compared with soil at soil depths of 20 to $30 \mathrm{~cm}$ and 40 to $50 \mathrm{~cm}$ in the $\mathrm{CK}$, the relative abundance of Ascomycota increased significantly in the aeration treatment, whereas the relative abundance of Basidiomycota decreased at different soil depths in the aeration treatment (Fig. 3B).

Key rhizosphere soil bacterial genera and fungal genera. As shown in Table 1, the proportion of Pseudomonas and Bacillus associated with phosphorus and potassium metabolism with aeration treatment at soil depths of 20 to 30 and 40 to $50 \mathrm{~cm}$ was higher than that with CK treatment, and the difference was significant $(P<0.05)$. For fungal genera, the proportion of Aspergillus associated with phosphorus metabolism was at soil depths of 0 to 10 and 40 to $50 \mathrm{~cm}$, with aeration treatment significantly higher than CK treatment $(P<0.01)$. Fusarium associated with OM decomposition at different soil depths was significantly higher than that with CK treatment $(P<0.01)$

Biomass accumulation and distribution. The biomass of the new leaves and fine roots $(<2 \mathrm{~mm})$ treated with aeration was $35.82 \%$ and $83.74 \%$ higher than that of the CK treatment, and the difference reached extremely significant level $(P<0.01)$. The biomass of new branches with aeration treatment was $24.56 \%$ higher significantly than that with the $\mathrm{CK}$ treatment $(P<0.05)$ (Table 2). For old leaves, old branches, and thick roots $(>2 \mathrm{~mm})$, there was no significant difference between the aeration and CK treatments $(P>0.05)$. These results show that the aeration treatment could significantly promote the growth of the new parts of the grape plants.

After pulse labeling, the ${ }^{13} \mathrm{C}$ fixed by photosynthesis was transferred and distributed in all parts of grape seedlings. The $\delta^{13} \mathrm{C}$ value of new branches and fine roots $(<2 \mathrm{~mm})$ with aeration irrigation was $163.37 \%$ and $118.05 \%$, respectively, and was extremely significantly higher than that of the CK treatment $(P<0.01)$. That of thick roots with aeration irrigation was $54.23 \%$ significantly higher than that of the $\mathrm{CK}$ treatment $(P<$ $0.05)$. The $\delta^{13} \mathrm{C}$ value of new leaves and old leaves was significantly lower than that of the CK treatment $(P<0.05)$. These results indicate that aeration irrigation can promote photoassimilation and the distribution and transport to new branches and roots.

Contents of $C, N, P, K$, and $C / N$ in Different Organs of 'Red Globe'. As shown in Table 3, the carbon content of new leaves and fine roots in aeration treatment was lower than that of $\mathrm{CK}$ treatment, and the carbon content of fine roots was significantly different $(P<0.05)$. The nitrogen, phosphorus, and 
A

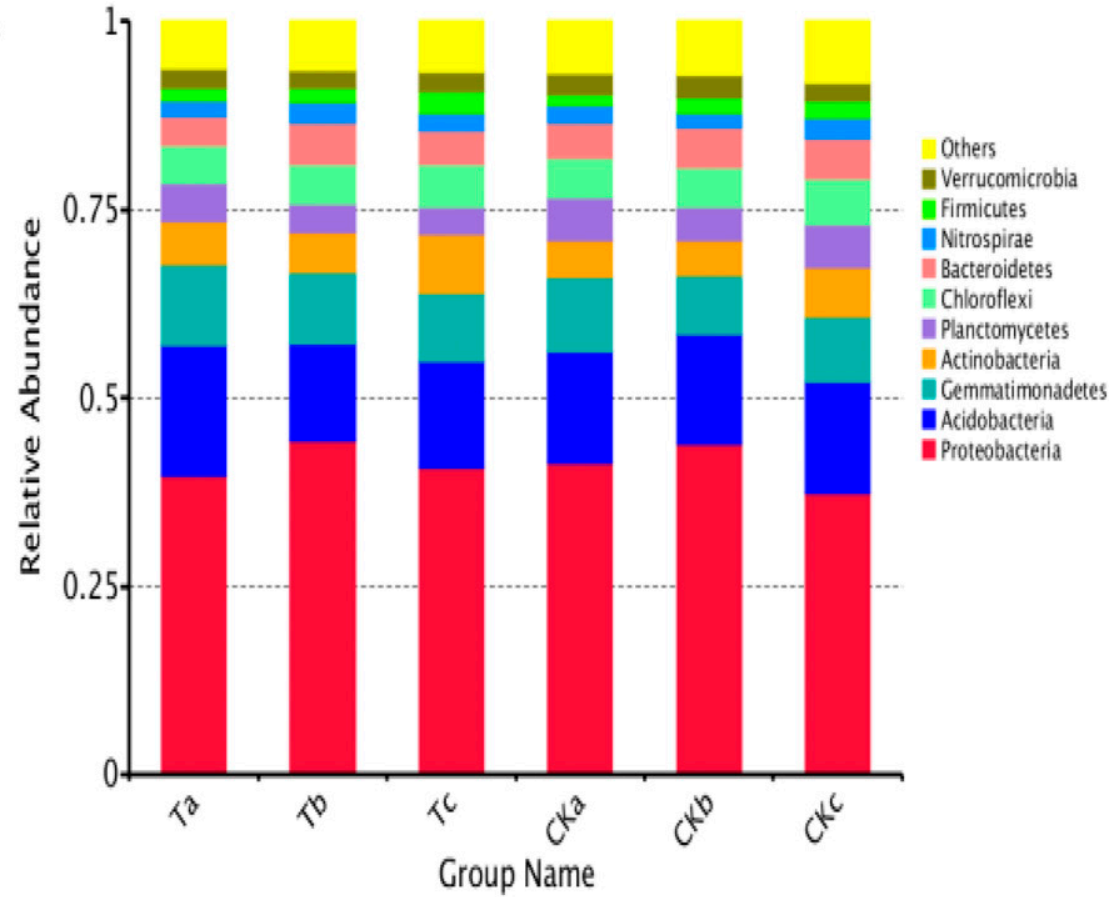

B

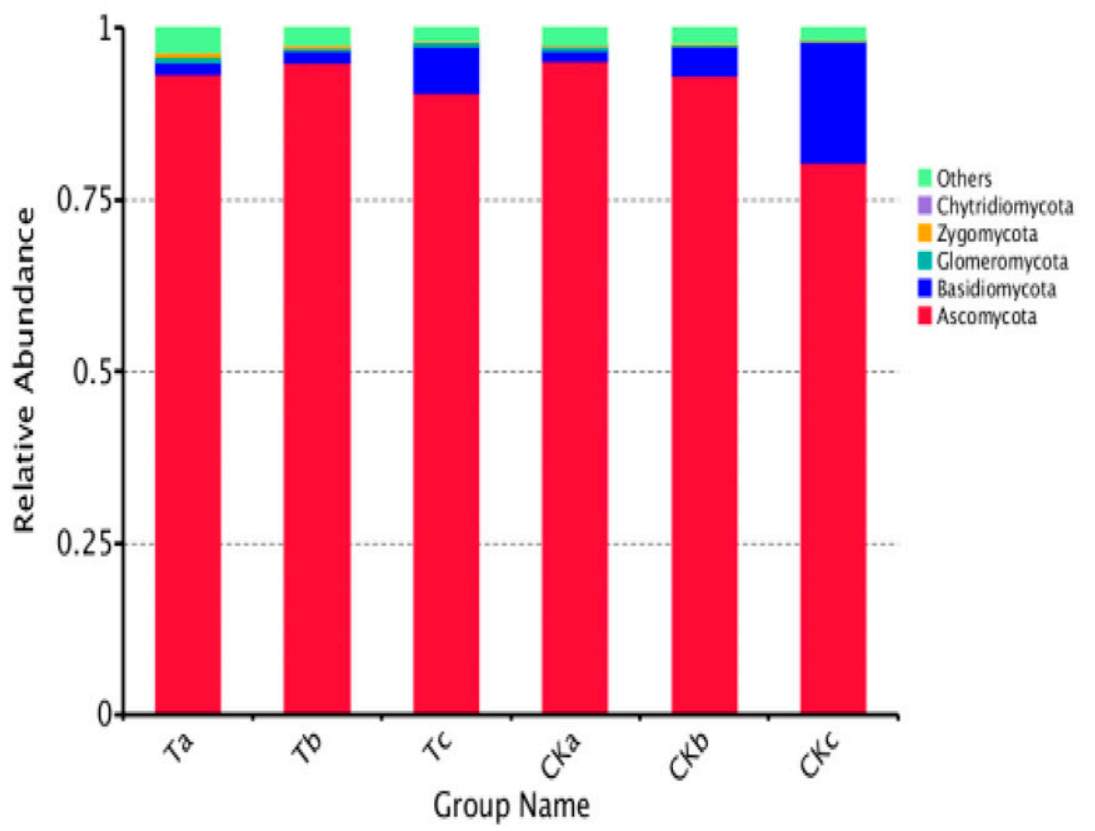

Fig. 3. Relative abundance of bacterial phyla (A) and fungal phyla (B) in aeration (T) and control (CK) groups at soil depths of 0 to 10 (a), 20 to 30 (b), and 40 to $50 \mathrm{~cm}$ (c). "Others" indicates phyla with an extremely low abundance.

potassium contents in fresh leaves were $25.94 \%, 18.56 \%$, and $15.13 \%$ higher than those in leaves of CK $(P<0.05)$, respectively, and the nitrogen, phosphorus and potassium contents in fine roots were $8.27 \%, 9.10 \%$, and $12.12 \%$ higher than those in $\mathrm{CK}(P<0.05)$. For the total content of $\mathrm{P}$ and $\mathrm{K}$, it can be seen that new leaves and fine roots of aeration treatment was significantly higher than that of $\mathrm{CK}(P<0.01)$. The $\mathrm{C} / \mathrm{N}$ of new leaves and fine roots was significantly lower than that of CK treatment $(P<0.05$; Table 3). aeration irrigation can increase soil respiration and promote the volatilization of soil $\mathrm{CO}_{2}$, but in our study, the soil respiration intensity of the aeration treatment was lower than that of CK treatment from 10:00 AM to 12:00 PM after aeration treatment, due to aeration treatment promoting the exchange of gas in the root zone soil and decreasing the $\mathrm{CO}_{2}$ content of soil in the root region. After that, the soil respiration intensity of the aeration treatment increased rapidly; this result is consistent with Hou et al. (2016).

Soil bacteria are an important component of soil microorganisms. Most of the dominant bacteria are basically consistent in the soil and include $\approx 10$ bacterial groups (Philippot et al., 2010). Phylum abundance analysis revealed that Proteobacteria, Actinobacteria, Bacteroidetes, and Acidobacteria were the top bacterial phyla in all soil samples, with some variation in relative abundance. This finding was similar to the results of Sun et al. (2014). After treatment for $90 \mathrm{~d}$, the soil with aeration treatment at the same depth was found to have higher abundance of Cytophagia and Nitrospira and a lower abundance of Planctomycetes compared with the soils from the CK treatment. Reduction of Planctomycetes abundance was observed in aeration-treated soils, presumably resulting from the anaerobic nature of these bacteria (Graca et al., 2016). In contrast, Cytophagia and Nitrospira are aerobic bacteria (Parfenova et al., 2013), and their increase suggests that aeration treatment increased the oxygen content in the soil. The results of this study show that rhizosphere aeration through SDI with tanks could promote the activity and reproduction of aerobic bacteria and decrease the growth of anaerobic bacteria.

Ascomycota and Basidiomycota were the most abundant fungal phyla in all of the soil samples, consistent with McGuire et al. (2013) and Schmidt et al. (2013). The abundance of Ascomycota increased significantly with aeration treatment at soil depths of 20 to 30 and 40 to $50 \mathrm{~cm}$, whereas the abundance of Basidiomycota decreased. To the best of our knowledge, no other reports have described the relationship between aeration and Ascomycota or Basidiomycota. Additionally, when comparing phylum abundance in soil samples, enrichment of Ascomycota and depletion of Basidiomycota in aerated soils may be associated with higher oxygen content. Further studies are needed to assess the effects of aeration treatment on these two most common fungal phyla.

Bacteria are the most diverse microbial community in soil. Their community characteristics are sensitive to changes of soil nutrients, $\mathrm{pH}$ values, and other external conditions and can reflect changes in soil quality in a timely manner (Vega et al., 2013). The Nitrosospira is a kind type of ammonia oxidizing bacteria, and aeration treatment could significantly increase the Nitrosospira in the study (Zhao et al., 2017). The results showed that rhizosphere aeration can increase the amount of ammonia-oxidizing bacteria 
in soil and accelerate the transformation of ammonia nitrogen into nitrate nitrogen. The results of key rhizosphere soil bacterial genera and fungal genera showed that aeration treatment could promote the growth of phosphate-solubilizing and potassiumsolubilizing microorganisms, increase the availability of soil phosphorus and potassium, and promote the uptake of phosphorus and potassium by plants. Aeration irrigation also promoted the growth of Fusarium related to OM decomposition and accelerated the decomposition of $\mathrm{OM}$ at a depth of 20 to $30 \mathrm{~cm}$.
Several studies have shown that aeration irrigation can significantly increase the yield and quality of crops, especially in clay and salinized soil (Bhattarai, S. et al., 2008; Shahien et al., 2014). The results of this study showed that aeration irrigation can promote the growth of new parts of grape plants, which is consistent with the previous studies on annual crops (Bhattarai et al., 2004). Carbon isotopic tracing showed that aeration irrigation can be more conducive to carbon allocation and transport to the new branches and fine roots than CK treatment, suggesting that aeration irrigation may have the potential

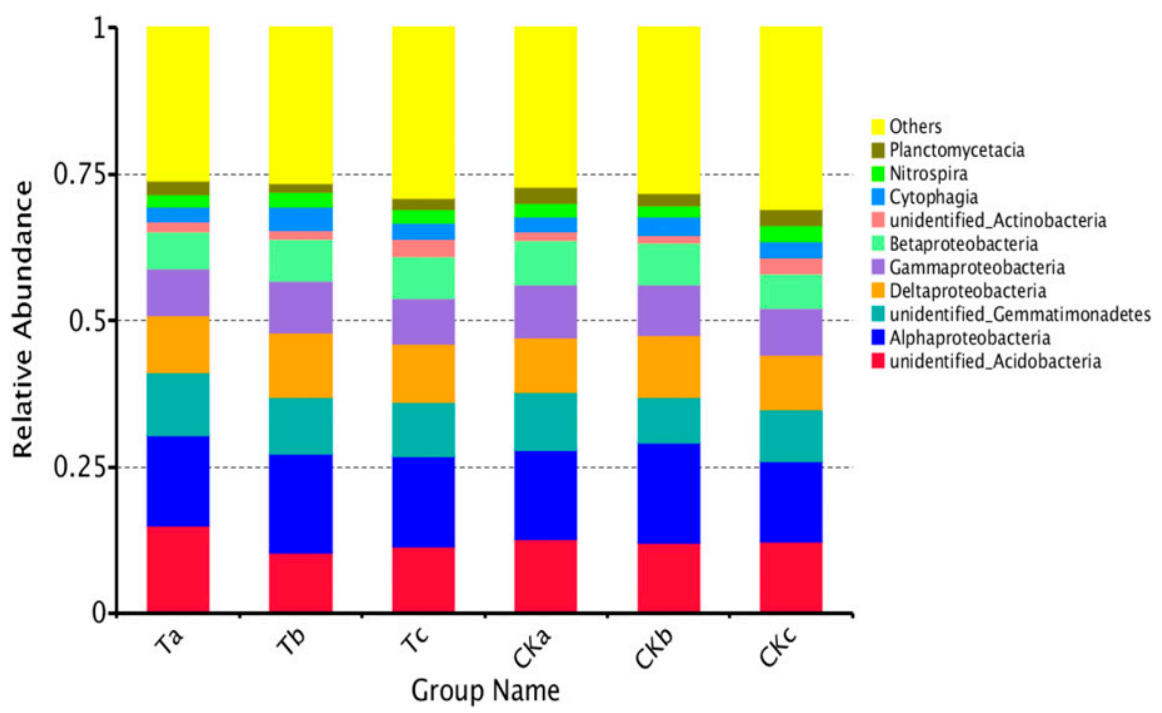

Fig. 4. Relative abundance of bacterial classes in the aeration (T) and control (CK) groups at soil depths of 0 to $10 \mathrm{~cm}$ (a), 20 to 30 (b), and 40 to $50 \mathrm{~cm}$ (c). "Others" indicates phyla with extremely low abundance.

advantage of promoting plant carbon fixation, but further studies are needed in a long period of growth.

Bhattarai et al. (2015) found that aeration irrigation could effectively promote uptake of phosphorus and potassium in plant leaves. The results showed that aeration irrigation promoted the accumulation of nitrogen, phosphorus, and potassium in new leaves and fine roots, and the total content of phosphorus and potassium was significantly higher than that of CK treatment. This may be related to the fact that aeration irrigation can increase the number of $\mathrm{P}$ - and $\mathrm{K}$-solubilizing bacteria and promote the decomposition of $\mathrm{P}$ and $\mathrm{K}$ in soil (Table 1). Previous studies (Lu et al., 2015) have shown that plant $\mathrm{C} / \mathrm{N}$ ratio was higher under adversity and lower under favorable conditions. In this study, the $\mathrm{C} / \mathrm{N}$ ratio of new leaves and fine roots was lower than that of CK treatment. We speculate that aerated irrigation can provide a better environment for plant root growth and promote plant growth compared with CK treatment.

\section{Conclusions}

Aeration irrigation through SDI with tanks regulated $\mathrm{O}_{2} / \mathrm{CO}_{2}$ content in rhizosphere soil and accelerated air exchange in rhizosphere soil. Aeration through SDI with tanks enhanced the growth of aerobic Cytophagia and Nitrospira, inhibited the growth of anaerobic Planctomycetes, and increased the abundance of fungi and bacteria at a depth of 40 to $50 \mathrm{~cm}$. It promoted the growth of new leaves, fine roots, and new branches of grape; increased the accumulation of nitrogen, phosphorus, and potassium in new leaves and fine roots; and made photoassimilation distribute

Table 1. Effect of aeration irrigation on key rhizosphere soil bacterial genera and fungal genera.

\begin{tabular}{|c|c|c|c|c|c|}
\hline Soil depth $(\mathrm{cm})$ & Treatment & Pseudomonas & Aspergillus & Bacillus & Fusarium \\
\hline$\overline{0-10}$ & $\mathrm{Ta}$ & $0.0032 \pm 0.0002 \mathrm{a}$ & $0.0107 \pm 0.0068 \mathrm{~A}$ & $0.022 \pm 0.0008 \mathrm{a}$ & $0.054 \pm 0.0061 \mathrm{~A}$ \\
\hline $20-30$ & $\mathrm{~Tb}$ & $0.0038 \pm 0.0001 \mathrm{a}$ & $0.0023 \pm 0.00029 a$ & $0.026 \pm 0.0004 \mathrm{a}$ & $0.037 \pm 0.0053 \mathrm{~A}$ \\
\hline & $\mathrm{CKb}$ & $0.0033 \pm 0.0007 \mathrm{~b}$ & $0.0024 \pm 0.00084 \mathrm{a}$ & $0.020 \pm 0.0004 \mathrm{~b}$ & $0.023 \pm 0.0066 \mathrm{~B}$ \\
\hline & $\mathrm{CKc}$ & $0.0032 \pm 0.0004 \mathrm{~b}$ & $0.0055 \pm 0.0019 \mathrm{~B}$ & $0.022 \pm 0.0013 \mathrm{~b}$ & $0.018 \pm 0.0023 \mathrm{~B}$ \\
\hline
\end{tabular}

Values are mean \pm SE. Data followed by different capital letters in a column indicate a highly significant difference $(P<0.01)$; different lowercase letters in a column indicate significant difference $(P<0.05)$.

Table 2. Effects of aeration irrigation on the dry matter weight and $\delta^{13} \mathrm{C}$ of different parts of 'Red Globe'.

\begin{tabular}{llrrrrrr}
\hline & Treatment & \multicolumn{1}{c}{ New leaves } & \multicolumn{1}{c}{ Old leaves } & \multicolumn{1}{c}{ Old branches } & New branches & Fine roots $(<2 \mathrm{~mm})$ & Thick roots $(>2 \mathrm{~mm})$ \\
\hline Dry matter weight $(\mathrm{g})$ & Aeration & $20.21 \pm 1.01 \mathrm{~A}$ & $9.84 \pm 0.06 \mathrm{a}$ & $28.06 \pm 2.78 \mathrm{a}$ & $23.58 \pm 1.35 \mathrm{a}$ & $15.03 \pm 0.78 \mathrm{~A}$ & $44.45 \pm 5.66 \mathrm{a}$ \\
& CK & $14.88 \pm 1.15 \mathrm{~B}$ & $9.56 \pm 0.04 \mathrm{a}$ & $26.53 \pm 3.22 \mathrm{a}$ & $18.93 \pm 2.13 \mathrm{~b}$ & $8.18 \pm 1.66 \mathrm{~B}$ & $45.29 \pm 8.39 \mathrm{a}$ \\
$\delta^{13} \mathrm{C}(\% \mathrm{oo})$ & Aeration & $9.76 \pm 0.57 \mathrm{~B}$ & $-11.40 \pm 1.03 \mathrm{~b}$ & $-18.51 \pm 1.64 \mathrm{a}$ & $92.84 \pm 5.25 \mathrm{~A}$ & $117.20 \pm 9.83 \mathrm{~A}$ & $26.96 \pm 1.59 \mathrm{a}$ \\
& CK & $19.02 \pm 1.23 \mathrm{~A}$ & $-4.08 \pm 0.69 \mathrm{a}$ & $-12.73 \pm 1.37 \mathrm{a}$ & $35.25 \pm 2.31 \mathrm{~B}$ & $53.75 \pm 4.66 \mathrm{~B}$ & $17.48 \pm 1.62 \mathrm{~b}$ \\
\hline
\end{tabular}

Values are mean \pm SE. Data followed by different capital letters in a column indicate a highly significant difference $(P<0.01)$; different lowercase letters in a column indicate a significant difference $(P<0.05)$.

Table 3. Contents of $\mathrm{C}, \mathrm{N}, \mathrm{P}$, and $\mathrm{K}$ in new leaves and fine roots of grape seedlings and $\mathrm{C} / \mathrm{N}$.

\begin{tabular}{|c|c|c|c|c|c|c|c|c|}
\hline & Treatment & $\mathrm{C}(\mathrm{mg} / \mathrm{g})$ & $\mathrm{N}(\mathrm{mg} / \mathrm{g})$ & $\mathrm{C} / \mathrm{N}$ & $\mathrm{P}(\mathrm{mg} / \mathrm{g})$ & $\mathrm{K}(\mathrm{mg} / \mathrm{g})$ & Total $\mathrm{P}$ content $(\mathrm{mg})$ & Total $\mathrm{K}$ content $(\mathrm{mg})$ \\
\hline New leaves & Aeration & $415.17 \pm 21.79 \mathrm{a}$ & $26.7 \pm 2.39 \mathrm{a}$ & $15.55 \pm 0.89 b$ & $1.98 \pm 0.25 \mathrm{a}$ & $9.45 \pm 0.74 \mathrm{a}$ & $41.07 \pm 3.63 \mathrm{~A}$ & $190.62 \pm 8.23 \mathrm{~A}$ \\
\hline Fine roots & Aeration & $383.82 \pm 24.45 b$ & $21.34 \pm 1.16 \mathrm{a}$ & $17.99 \pm 1.04 b$ & $1.68 \pm 0.16 \mathrm{a}$ & $10.82 \pm 1.22 \mathrm{a}$ & $25.37 \pm 3.21 \mathrm{~A}$ & $312.62 \pm 12.49 \mathrm{~A}$ \\
\hline
\end{tabular}

Values are mean \pm SE. Data followed by different capital letters in a column indicate a highly significant difference $(P<0.01)$; different lowercase letters in a column indicate a significant difference $(P<0.05)$. 
to the new branches and fine roots. The results indicated that aeration irrigation through SDI with tanks can promote plant growth. This maybe because aeration irrigation can enhance air exchange and microbial structure in the rhizosphere. This study shows that the aeration irrigation technology has a potential application in greenhouse cultivation, but further study is needed for aeration period, frequency, and intensity.

\section{Literature Cited}

Abbott, L.K. and D.V. Murphy. 2003. Soil Biological Fertility: A Key to Sustainable Land Use in Agriculture. Kluwer Academic Publishers, Dordrecht, the Netherlands.

Abuarab, M., E. Mostafa, and M. Ibrahim. 2013. Effect of air injection under subsurface drip irrigation on yield and water use efficiency of corn in a sandy clay loam soil. J.A.R. 4(6):493499.

An, T., S. Schaeffer, S. Li, S. Fu, J. Pei, H. Li, J. Zhuang, M. Radosevich, and J.K. Wang. 2015. Carbon fluxes from plants to soil and dynamics of microbial immobilization under plastic film mulching and fertilizer application using $13 \mathrm{c}$ pulse-labeling. Soil Biol Biochem. 80(80):53-61.

Bhattarai, S.P., S. Huber, and D.J. Midmore. 2004. Aerated subsurface irrigation water gives growth and yield benefits to zucchini, vegetable soybean and cotton in heavy clay soils. Ann. Appl. Biol. 144(3):285-298.

Bhattarai, S.P., L. Pendergast, and D.J. Midmore. 2006. Aeration improves yield and water use efficiency of irrigated tomato in heavy clay and saline soils. Scientia Hort. 108:278-288.

Bhattarai, S.P., D.J. Midmore, and L. Pendergast. 2008. Yield, water-use efficiencies and root distribution of soybean, chickpea and pumpkin under different subsurface drip irrigation depths and oxygation treatments in vertisols. Irrig. Sci. 26(5):439-450.

Bhattarai, S.P., R.J. Balsys, P. Eichler, D.J. Midmore, and D. Wassink. 2015. Dynamic changes in bubble profile due to surfactant and tape orientation of emitters in drip tape during aerated water irrigation. Intl. J. Multiphas. Flow. 75:137-143.

Ben-Noah, I. and S.P. Friedman. 2016. Aeration of clayey soils by injecting air through subsurface drippers: Lysimetric and field experiments. Agr. Water. Mgt. 176:222-233.

Carpenter-Boggs, L., P.D. Stahl, M.J. Lindstrom, and T.E. Schumacher. 2003. Soil microbial properties under permanent grass, conventional tillage, and no-till management in south dakota. Soil Tillage Res. 71:15-23.

Fierer, N., J. Ladau, J.C. Clemente, J.W. Leff, S.M. Owens, K.S. Pollard, R. Knight, J.A. Gilbert, and R.L. McCulley. 2013. Reconstructing the nicrobial diversity andfunction of preagricultural tallgrass prairie soils in the United States. Science 342:621-624.

Greenway, H., W. Armstrong, and T.D. Colmer. 2006. Conditions leading to high $\mathrm{CO}_{2}(>5 \mathrm{kpa})$ in water logged-flooded soils and possible effects on root growth and metabolism. Ann. Bot-London. 98(1):9-32.
Graca, A.P., R. Calisto, and O.M. Lage. 2016 Planctomycetes as novel source of bioactive molecules. Front. Microbiol. 7(389):1241.

Hou, H., H. Chen, H. Cai, F. Yang, D. Li, and F. Wang. 2016. $\mathrm{CO}_{2}$ and $\mathrm{N}_{2} \mathrm{O}$ emissions from lou soils of greenhouse tomato fields under aerated irrigation. Atmos. Environ. 132:69-76.

Ityel, E., A. Ben-Gal, M. Silberbush, and N. Lazarovitch. 2014. Increased root zone oxygen by a capillary barrier is beneficial to bell pepper irrigated with brackish water in an arid region. Agr. Water Mgt. 31:108-114.

Ji, Y.Y., G.L. Zhang, R. Zhang, Y.S. Liu, D.L. Yang, and C.L. Wang. 2013. Effects of different tillage modes on metabolic functional diversity of soil microbial community. Chin Sci Bull. 29:117-123.

Lau, J.A. and J.T. Lennon. 2011. Evolutionary ecology of plant-microbe interactions: Soil microbial structure alters selection on plant traits. New Phytol. 192:215-224.

Li, Y., W. Niu, J. Wang, L. Liu, M. Zhang, and J. Xu. 2016a. Effects of artificial soil aeration volume and frequency on soil enzyme activity and microbial abundance when cultivating greenhouse tomato. Soil Sci. Soc. Amer. J. 80(5):1208-1221.

Li, Y., W. Niu, M. Dyck, J. Wang, and X. Zou. 2016b. Yields and nutritional of greenhouse tomato in response to different soil aeration volume at two depths of Subsurface drip irrigation. Sci. Rep-Uk. 6:39307.

Lu, Y, J. Yamaguchi, and T. Sato. 2015. Integration of $\mathrm{C} / \mathrm{N}$-nutrient andmultiple environmental signals into the ABA signaling cascade. Plant Signal Behav. 10(12):e1048940.

Lei, H., Z. Ming, Z. Zhang, L. Xin, J. Xu, and H. Pan. 2015. Growth and quality of greenhouse tomato undercycle aerated subsurface drip irrigation. Irrigation Machinery Engineering 33(3):253-259.

McGuire, K.L., S.G. Payne, M.I. Palmer, C.M. Gillikin, D. Keefe, S.J. Kim, S.M. Gedallovich, J. Discenza, R. Rangamannar, J.A. Koshner, A.L. Massmann, G. Orazi, A. Essene, J.W. Leff, and N. Fierer. 2013. Digging the new york city skyline: Soil fungal communities in green roofs and city parks. PLoS One 8(3):E58020.

Nawaz, M.F., G. Bourrié, and F. Trolard. 2013. Soil compaction impact and modelling a review. Agron. Sustain. Dev. 33(2):291-309.

Niu, W.Q., W.T. Fan, N. Persaud, and X.B. Zhou. 2013. Effect of post-irrigation aeration on growth and quality of greenhouse cucumber. Pedosphere 23:790-798.

Parfenova, V. V., A.S. Gladkikh, and O.I. Belykh. 2013. Comparative analysis of biodiversity in the planktonic and biofilm bacterial communities in Lake Baikal. Microbiology 82(1): 91-101

Philippot, L., S.G. Andersson, T.J. Battin, J.I. Prosser, J.P. Schimel, W.B. Whitman, and S. Hallin. 2010. The ecological coherence of high bacterial taxonomic ranks. Nat. Rev. Microbiol. 8(7):523-529.

Rücknagel, J., B. Hofmann, P. Deumelandt, F. Reinicke, J. Bauhardt, K.J. Hülsbergen, and O. Christen. 2015. Indicator based assessment of the soil compaction risk at arable sites using the model repro. Ecol. Indic. 52:341-352.
Shahien, M.M., M.E. Abuarab, and E. Magdy. 2014. Root aeration improves yield and water use efficiency of irrigated potato in sandy clay loam soil. I.J.A.R. 2:310-320.

Shen, Z., Y. Ruan, B. Wang, S. Zhong, L. Su, R. Li, and Q. Shen. 2015. Effect of biofertilizer for suppressing fusarium, wilt disease of banana as well as enhancing microbial and chemical properties of soil under greenhouse trial. Appl Soil Ecol. 93:111-119.

Smith, P., H. Haberl, A. Popp, K.H. Erb, C. Lauk, R. Harper, F.N. Tubiello, A. de Siqueira Pinto, M. Jafari, S. Sohi, O. Masera, H. Böttcher, G Berndes, M. Bustamante, H. Ahammad, H. Clark, H. Dong, E.A. Elsiddig, C. Mbow, N.H. Ravindranath, C.W. Rice, C.R. Abad, A. Romanovskaya, F. Sperling, M . Herrero, J.I. House, and S . Rose. 2013. How much landbased greenhouse gas mitigation can be achieved without compromising food security and environmental goals? Glob. Change Biol. 19:2285-2302.

Schmidt, P.A., M. Bálint, B. Greshake, C. Bandow, J. Römbke, and I. Schmitt. 2013. Illumina metabarcoding of a soil fungal community. Soil Biol. Biochem. 65(5):128-132.

Sun, M., T. Xiao, Z. Ning, E. Xiao, and W. Sun. 2014. Microbial community analysis in rice paddy soils irrigated by acid mine drainage contaminated water. Appl. Microbiol. Biot 99:2911-2922.

Vega, J.A., T. Fontúbel, A. Merino, C. Fernandez, A. Ferreiro, and E. Jiménez. 2013. Testing the ability of visual indicators of soil burn severity to reflect changes in soil chemical and microbial properties in pine; forests and shrubland. Plant Soil. 369(1-2):73-91.

Werner, R.A. and W.A. Brand. 2001. Referencing strategies and techniques in stable isotope ratio analysis. Rapid Commun.Mass Sp. 15: 501e519.

Yu, K., S.L. Yu, H.F. Liu, W.J. Wang, W.B. Xu, and Z.C. Bai. 2014. Design of underground container of reserving fertilizer and water drip irrigation system and its effects on the plant growth and water use efficiency of "Cabernet Sauvignon" grape. Fruit Sci. 31:386-393.

Yu, K., S.L. Yu, H.F. Liu, W.J. Wang, W.B. Xu, and J.L. Sun. 2015. Effects of alternative partial root-zone drip irrigation on growth of root and shoot of Cabernet Sauvignon grape seedlings. Trans. Chin. Soc. Agr. Eng. 31:113-120.

Zhao, F.Y., X. Yang, M.M. Dong, Y. Jiang, K. Yu, and S.L. Yu. 2017. Aeration irrigation improving grape rhizosphere soil chemical properties and bacterial community structure in arid area. Trans. Chin. Soc. Agr. Eng. 33(22):119-126.

Zhao, F.Y., S.L. Yu, J.L. Sun, Y. Jiang, H.F. Liu, and K. Yu. 2018. Effect of rhizosphere aeration on growth and absorption, distribution and utilization of $\mathrm{NH}_{4}{ }^{+}-\mathrm{N}$ and $\mathrm{NO}_{3}{ }^{-} \mathrm{N}$ of Red Globe grape seedling. Trans. Chin. Soc. Agr. Mach. 49(1):228-234.

Zhu, D., L. Zhang, Z.X. Wei, X.Y. Liu, Z.F. Zhou, X.Z. Dai, X.F. Wang, Z.Q. Xia, X.Q. Wu, J.J. Wei, and L. Fu. 2014. Effect of bacterial manure on soil physicochemical properties and microbial community diversity in rhizosphere of highland barley. Acta Pedologic Sinica. 51:627-637. 